\title{
MODEL TRAINING NEEDS ANALYSIS UNTUK MEMBENTUK PERILAKU INOVATIF SDM INDUSTRI KECIL SEPATU DI JAWA TIMUR
}

\author{
Anita Kristina \\ anita_amanda_ali@yahoo.com \\ Universitas Trunjoyo
}

\begin{abstract}
Market Extension and product inovation every moment is conducted by industry, this matter needs the better skill from the production to increase performance of innovative and understanding to new product.The aim of this research is to compile the model of Training Needs Analysis ( TNA) which is needed to identify the training requirement in order to overcome theworker competence in innovative performance, this is in the small industry. TNA is very important because TNA assists to find whether deficiencies of innovative performance can be improved with the training. The result of this research indicates that the innovative behavior is fundamental problem and become the main problem which must be finished with training. The result of this study indicates that TNA is shown in a model of concept of a system that is consist of input, process, and output. Process of analysis finds the discrepancy and cause from the problem of skill inovative. The output of this model is the training needs and non training needs.
\end{abstract}

Keywords: Model, Training Needs Analysis (TNA), Skill innovative.

\section{PENDAHULUAN}

Pergeseran dan peristiwa krisis ekonomi tahun 1997, membuktikan bahwa di tengahtengah porakporanda industri besar, industri kecil mampu berdiri kokoh. Pertumbuhan industri besar yang pesat (sebelum krisis) tidak didukung oleh industri kecil yang kuat sehingga pada saat krisis ekonomi industri besar sangat terpukul dan berdampak pada perekonomian nasional. Adanya berbagai pengaruh perubahan kondisi ekonomi tersebut menuntut semua industri untuk lebih membuka diri terhadap tuntutan perubahan dan upaya menyusun sebuah strategi baru agar tetap survive dalam dunia bisnis. Perubahan lingkungan bisnis meliputi aspek internal dan eksternal (Schuller dan Jackson, 1990: 57), perubahan internal dalam lingkungan bisnis meliputi permasalahan puncak (nilai dan budaya, hal, etika, serta program pengembangan), struktur organisasi (manajemen sumber daya strategis), budaya organisasi (filosofi sumber daya manusia), ukuran organisasional 
(pengendalian perilaku), dan perubahan eksternal dalam lingkungan bisnis meliputi tantangan global dan persaingan akan penguasaan pasar internasional, persaingan domestik dan internasional (kinerja karyawan dan pemberdayaan), karakteristik demografi (gender, pendapatan, glass-ceilling effect, minoritas, mayoritas, dan diversitas angkatan kerja), karakteristik angkatan kerja (tingkat pendidikan dan nilai budaya kerja), serta trend ekonomi dan organisasional yang meliputi perubahan skill dan pekerjaan, perubahan organisasi, kemajuan teknologi, otomatisasi, dan robotis.

Perubahan-perubahan di atas juga mempengaruhi iklim bisnis yang ada di sekitar perusahaan, begitu juga pada industri kecil, menuntut sebuah perubahan kinerja, agar tetap survive dalam bisnis. Perubahan yang paling penting yang dapat dilakukan oleh perusahaan untuk mengimbangi perubahan iklim bisnis adalah dengan menambah kompetensi-kompetensi inti yang dimiliki oleh karyawannya, untuk itu diperlukan sebuah investasi yang efektif dan efisien. Salah satunya dengan pelatihan (training). Karena pelatihan diyakini sebagai sarana perubahan untuk meningkatkan skill, knowledge, dan ability. Perubahan yang mendasar adalah perubahan skill karena skill merupakan kebutuhan dasar seseorang untuk melakukan pekerjaannya dengan professional dan sesuai dengan yang diharapkan oleh perusahaan.

Penelitian ini mengkaji tentang pengembangan SDM industri kecil, dengan menyusun kebutuhan pelatihan. Pelatihan sangat dibutuhkan karena untuk dapat memenangkan persaingan, pengrajin atau pengusaha kecil, dan karyawannya harus meningkatkan ketrampilan pengembangan desain dan teknik pengerjaan sepatu. Program pengembangan SDM dalam berbagai bentuk untuk menciptakan iklim organisasi internal IK yang positif dan memberi kepuasan kerja merupakan cara yang sangat strategis dalam mengembangkan karyawan IK sepatu untuk meningkatkan kemampuan bersaing dengan pelaku industri dari negara lain (Kompas, 2005). Secara nasional, sepatu juga merupakan salah satu komoditi ekspor andalan industri kecil di Indonesia (Tambunan, 2002: 40).

Di Jawa Timur para produsen dan pengrajin tidak berdaya menghadapi masuknya produk sepatu impor yang harganya lebih murah di pasaran. Akibat kalah bersaing, kemampuan produksi hampir seluruh pengrajin sepatu di Jawa Timur saat ini hanya berkisar 30 persen hingga 70 persen dari kapasitas total terpasang. Berbagai upaya struktural dilakukan antara lain dengan usulan kepada pemerintah untuk menaikkan bea masuk produk sepatu impor dari 15 persen menjadi sekitar 35 persen (Kompas, 2005). Usulan ini tidak lain dimaksudkan untuk meningkatkan daya saing harga sepatu bagi industri dalam negeri termasuk dari Jawa Timur.

Pertumbuhan industri sepatu di Jawa Timur memiliki potensi yang sangat besar, industri sepatu merupakan produk unggulan di Jawa Timur. Terdapat 25 unit usaha kecil sepatu/alas kaki dengan jumlah tenaga kerja mencapai 1094 orang serta jumlah produksi mencapai 1.284.350 pada per tahunnya (Dinas Perindustrian dan Perdagangan Prop. 
Jatim, 2002). Unit usaha yang semakin berkembang diikuti dengan perubahan iklim bisnis dan iklim organisasi. Perubahan iklim tersebut secara tidak langsung mempengaruhi kinerja perusahaan. Terdapat beberapa fenomena dalam industri sepatu, yaitu karyawan produksi berpendidikan rendah, kepekaan terhadap pembaruan produk yang kurang, kurang memahami prosedur kerja dan tuntutan kebutuhan akan inovatif, situasi tersebut menuntut adanya kebutuhan pelatihan. Karena TNA diyakini sebagai strategi pengembangan SDM/perbaikan kinerja maka diperlukan penyusunan model untuk meningkatkan perilaku inovatif pada karyawan produksi bagi IK sepatu di Jawa Timur

Pengembangan SDM melalui pelatihan merupakan salah satu upaya perubahan yang dilakukan untuk mengikuti perubahan iklim bisnis dan internal. Pelatihan yang dibutuhkan yaitu pelatihan yang berdasarkan karakteristik individu, kepuasan kerja, dan budaya organisasi. Karakteristik individu yang bekerja di lingkungan IK ditandai dengan sejumlah keterbatasan terutama tingkat pendidikan yang rendah. Keterbatasan ini merupakan salah satu kendala serius bagi pengembangan IK di Jawa Timur terutama dalam beberapa aspek yakni jiwa entrepreneurship, manajemen, kreativitas, dan inovatif terhadap menghasilkan produk. Sedangkan kompetensi tersebut ialah kompetensi yang harus dimiliki oleh karyawan produksi. Penciptaan budaya kerja yang kondusif, sejalan dengan perubahan inovasi produk akan menciptakan kepuasan bagi karyawan produksi dan pada akhirnya pada kepuasan perusahaan. Sebenarnya di tangan merekalah, bagian penting dalam proses produksi, yaitu menghasilkan produk yang disenangi konsumen, produk yang inovatif, dan kreatif.

Berdasarkan keyakinan bahwa peningkatan kualitas SDM yang menghasilkan perilaku kerja positif dalam bentuk perilaku inovatif dari para karyawan IK sepatu yang dapat mendukung bagi peningkatan ketrampilan proses produksi dan penciptaan iklim kondusif yang mampu menciptakan kepuasan kerja, maka penelitian ini dirancang sedemikian rupa untuk memfokuskan diri pada keterkaitan antara model analisis kebutuhan pelatihan dan perilaku inovatif karyawan produksi pada industri kecil sepatu di Jawa Timur. Dengan perilaku karyawan yang inovatif, pengusaha IK sepatu di Jawa Timur diharapkan dapat bersaing dengan pengusaha lainnya.

\section{RERANGKA TEORETIS}

\section{Model}

Model merupakan suatu pola dari sesuatu yang dihasilkan dan menunjukkan suatu pola fungsi tertentu. Menurut Simarmata (1983: 9), model adalah suatu abstraksi dari realitas dengan hanya memusatkan perhatian pada beberapa bagian atau sifat dari kehidupan sebenarnya. 
Jenis-jenis model diklasifikasikan:

1. Kelas I, pembagian menurut fungsi:

a. Model deskriptif yaitu model yang hanya menggambarkan situasi sebuah sistem tanpa rekomendasi dan peramalan sebagai miniatur obyek yang dipelajari.

b. Model Prediktif yaitu model yang menggambarkan apa yang akan terjadi bila sesuatu terjadi.

c. Model Normatif, yaitu model yang menyediakan jawaban terbaik terhadap suatu persoalan. Model ini merekomendasikan tindakan-tindakan yang perlu diambil, disebut juga sebagai model simulatif. Masalah model normatif biasanya berbentuk penemuan nilai-nilai dari variabel yang dikendalikan sehingga akan menghasilkan manfaat yang besar seperti yang diukur oleh variasi hasil atau kriteria.

2. Model Kelas II, pembagian menurut struktur:

a. Model Klasik, yaitu model yang dalam suatu skala tertentu meniru sistem aslinya.

b. Model Analog, yaitu model yang meniru sistem aslinya dengan hanya mengambil beberapa karakteristik utama atau menggambarkan dengan benda atau sistem lain secara analog.

c. Model Simbolis, yaitu model yang menggambarkan sistem yang ditinjau dengan simbol-simbol, biasanya simbol-simbol matematik. Dalam hal ini diwakili dengan variabel-variabel dari karakteristik sistem yang ditinjau.

3. Model Kelas III, menurut Referensi waktu:

a. Model Statis, yaitu model yang tidak memasukkan waktu dalam perumusannya.

b. Model Dinamis, yaitu model yang mempunyai unsur waktu dalam perumusannya dan menunjukkan perubahan setiap saat akibat aktivitasnya.

4. Model Kelas IV, pembagian menurut Referensi Kepastian:

a. Model Deterministis, yaitu model yang di dalam setiap kumpulan nilai input hanya ada satu output yang unik, merupakan solusi dari model keadaan yang pasti.

b. Model Probabilistik, yaitu model yang mencakup distribusi probabilistik dari input atau proses dan menghasilkan suatu deretan harga bagi paling tidak satu variabel output disertai dengan kemungkinan-kemungkinan dari harga-harga tersebut.

c. Model Game, yaitu model yang merupakan teori permainan mengembangkan solusi-solusi optimum dalam menghadapi situasi yang tidak pasti.

5. Model Kelas V, pembagian menurut Generalitas;

a. Model Umum, yaitu model yang dapat diterapkan pada berbagai bidang fungsional.

b. Model Khusus yaitu model yang dapat diterapkan terhadap sebuah bidang usaha fungsional tertentu atau unik saja dan hanya dapat digunakan pada masalahmasalah tertentu.

Pengembangan model dalam penelitian ini termasuk dalam model normatif yaitu model yang dapat memberikan solusi terbaik dalam sebuah persoalan, yang dalam hal ini memberikan solusi terbaik dalam penyusunan model TNA untuk menyelesaikan permasalahan pada perilaku inovatif karyawan produksi. 


\section{Training Needs Analysis (TNA)/Analisis Kebutuhan Pelatihan}

\section{Definisi Training Needs Analysis}

Training needs analysis (TNA) adalah suatu studi sistematis tentang suatu masalah pendidikan dengan pengumpulan data dan informasi dari berbagai sumber, untuk mendapatkan pemecahan masalah atau saran tindakan selanjutnya (Mangkunegara, 2003: 72). Menurut Tovey (dalam Irianto, 2001;30) training needs analysis is simply an analysis of the workplace to specifically determinate what training needs to be done so that money, time and effort is not wasted on unnecessary training activities. Dari definisi keduanya maka dapat dikatakan bahwa TNA merupakan analisis sederhana yang dilakukan terlebih dulu untuk menghindarkan pada usaha-usaha yang tidak perlu dilakukan pelatihan. TNA sangat penting dilakukan karena keputusan didasarkan pada analisis yang ada. Training hanya dapat dilakukan jika hal tersebut dilakukan dengan tepat dan pada waktu yang tepat sehingga TNA ini berperan penting.

\section{Makna dan Fungsi Training Needs Analysis}

Adanya perubahan lingkungan bisnis mengakibatkan perusahaan untuk merespon perubahan tersebut dengan program pelatihan yang baru. Ada dua hal pokok yang harus diketahui oleh manajer (Irianto, 2001:33) yaitu; symptoms of the need for change dan cause(s) of those symptoms.Symtoms of the need for change adalah sebuah masalah yang kemungkinan muncul dari beberapa sumber. Sedangkan cause of the symptoms adalah sebuah faktor yang harus diubah sedemikian rupa untuk mengurangi symptoms atau problem tersebut.

Untuk mengatasi dua hal pokok tersebut dibutuhkan sebuah model TNA, karena TNA diakui sebagai model yang dirancang untuk menentukan the cause(s) yang telah memunculkan symptoms tersebut (Irianto, 2001:33). Dengan demikian makna TNA menurut Camp and Huzaezo (dalam Irianto, 2001:33) sebagai the examination or diagnostic portion of the training system. Symptoms yang diuji oleh TNA sering merujuk pada persepsi performance deficiencies yang timbul manakala terdapat perbedaan (gap) antara expected dan perceived job performance.

Dan menurut Tovey (dalam Irianto, 2001:33) TNA pada dasarnya merupakan a process of comparing the actual performance of individuals with the standart of performance at which they are expected to operate. Berdasarkan makna yang demikian inilah maka TNA memiliki berbagai fungsi yaitu:

1. collect information on the skill, knowledge and feeling of the performers.

2. collect information on the job content and contex.

3. defined the desired and actual performance in useful detail.

4. involve stakeholders and build support.

5. provide data for planning. 


\section{Jenis Training Needs Analysis (TNA)}

TNA merupakan suatu proses sehingga secara umum TNA dapat dikategorikan ke dalam dua jenis yaitu (Irianto, 2001: 34):

1. Reaktif

TNA reaktif menurut Camp and Huszezo (dalam Irianto, 2001:34) dapat terjadi bila the perceived performance deficiency is a discrepancy between perceived and expected performance for the emplyee's current job. Sesuai namanya TNA jenis ini sifatnya reaktif dimana sering terjadi perbedaan tingkat persepsi di antara para pengambil keputusan.

2. Proaktif

TNA jenis ini dirancang to respond to the perception that current job behaviour reflects an inability to meet future standards or expectations. Sesuai namanya pula bahwa TNA ini mencoba bersikap proaktif atas sejumlah fenomena dimana semuanya diarahkan pada refleksi kemampuan kinerja karyawan terhadap standar dan harapan yang sangat mungkin akan mengalami perubahan di masa mendatang. Terdapat dua varian dalam TNA proaktif yaitu; preventive approach dan developmental approach. Dalam pendekatan preventive dalam TNA sengaja dirancang untuk menyakinkan bahwa seorang karyawan akan dapat memenuhi future expectation dari current job-nya, sedangkan developmental purpose merupakan buah hasil persepsi manajer sebagai supervisor yang menilai potensi yang kini dapat dilihat dan kelak dapat dikembangkan pada level tertinggi. Berdasarkan persepsi inilah manajer dapat merancang program pelatihan untuk karyawan potensial tersebut (Irianto, 2001: 35).

\section{Proses Training Needs Analysis (TNA)}

Menurut Tovey (dalam Irianto, 2001;36) terdapat enam tahapan pokok dalam proses TNA,yaitu:

1.Dokumentasi Masalah

Dokumentasi masalah merupakan tahap pertama dalam proses TNA dimana manajer berupaya menemukan sebanyak mungkin persoalan dan kemudian mendokumentasikannya sehingga akhirnya dapat dibuat pertimbangan di dalam memutuskan tentang berbagai persoalan yang berhubungan dengan skill gap dan bagaimana hal itu dapat mengarahkan pada suatu tindakan analisis. Salah satu cara terbaik untuk melakukan tahap pertama ini adalah melalui wawancara dengan beberapa staf atau pihak tertentu yang terlibat dengan munculnya sejumlah isu permasalahan (Irianto, 2001: 36).

\section{Investigasi Masalah}

Setelah melakukan dokumentasi masalah maka manajer menginvestigasi segala kemungkinan yang menjadi penyebab serta duduk persoalan apa yang sebenarnya. Investigasi permasalahan tidak dilakukan secara indepth namun sudah dianggap cukup memadai jika memungkinkan manajer membuat verifikasi bahwa memang telah terjadi persoalan serius dan kemudian memutuskan apakah pelatihan diperlukan atau tidak untuk mengatasinya (Irianto, 2001: 39). 
3. Merencanakan Kebutuhan Analisis

Setelah menginvestigasi persoalan dengan seksama, giliran manajer memulai merencanakan membuat kerangka analisisnya. Dalam hal ini manajer mengidentifikasi pelaksanaan analisis itu sendiri berdasarkan beberapa pertimbangan yaitu; urgensi persoalan, kapasitas manajer dalam konteks penyelesaian masalah akses terhadap beberapa pihak dapat diajak konsultasi, serta segala sesuatu yang berkaitan dengan sarana pendukung untuk membuat analisis.

Dalam tahapan proses ini perlu ditambahkan lagi adanya tingkatan TNA, meliputi (Irianto, 2001:38):

a. Analisis organisasional

Analisis ini berhubungan dengan kebutuhan organisasi secara keseluruhan diikuti dengan identifikasi bagaimana pelatihan dapat dieksploitasi sedemikian rupa untuk mencapai tujuan organisasi. Analisis ini berupaya memahami apa yang sesungguhnya dibutuhkan oleh organisasi.

b. Analisis Jabatan

Analisis jabatan ini dapat dikaitkan dengan kebutuhan terhadap pekerjaan tertentu dalam organisasi dan dapat digunakan sebagai informasi tentang substansi utama pekerjaan tersebut untuk selanjutnya dikembangkan standar kinerja. Di samping itu juga dimungkinkan untuk mengidentifikasi tingkat skill, knowledge dan ability yang dibutuhkan untuk mencapai standar yang telah ditetapkan.

c. Analisis Personal

Pada tingkatan ini manajer mengkaitkannya dengan kebutuhan individual dalam organisasi dan sampai sejauh mana kinerja yang telah dicapainya.

\section{Pemilihan Teknik Analisis}

Tahapan proses ini sangat penting karena manajer menetapkan dengan teknik apa analisis akan dilakukan. Pemilihan teknik dilakukan dengan cermat untuk memastikan bahwa data yang diperoleh adalah sesuai dengan teknik analisisnya. Terdapat berbagai macam pilihan teknik analisis (Irianto, 2001:39) yaitu; survey of organizational data, survey and questionnaires, observations, performance analysis, task analysis, employee appraisal, work samples dan sebagainya.

5. Melakukan Analisis

Dalam tahapan ini manajer harus mengidentifikasikan kepada semua pihak yang terlibat tentang jadwal pelaksanaan analisis sekaligus ijin dari pihak yang berkepentingan. Pada tahap ini manajer memiliki kesempatan atas bentuk format analisis sebagai laporan kepada senior manajer (Irianto, 2001: 39).

6.Analisis Data

Analisis data harus sesuai dengan metode pelaporan yang lazim digunakan secara umum karena akan dibaca oleh pihak lain. 


\section{Pelaporan Temuan}

Tahapan ini adalah tahapan terakhir dari proses TNA, manajer membuat laporan tentang temuan sekaligus rekomendasi pemecahan masalah persoalan.

\section{Perilaku Inovatif}

Perilaku inovatif (innovative behavior) dari individu merupakan isu yang sangat menarik dalam setiap pembicaraan tentang dinamika organisasi. Berdasarkan karakteristik dan latar belakang individu yang berbeda, maka perilaku inovatif masing-masing individu juga tidak sama (Barney dan Griffin, 2000:300). Organisasi terdiri atas berbagai individu yang memiliki karakteristik dan latar belakang yang berbeda. Akibatnya praktek manajemen SDM dihadapkan pada sejumlah persoalan tentang isu keanekaragaman karyawan atau workforce diversity (D'Netto dan Sohal, 1999:23) yang berdampak pada munculnya perbedaan perilaku individu dalam organisasi. Isu keberagaman atau keanekaragaman menjadi sangat menarik untuk diperhatikan karena keberhasilan organisasi tergantung pada karyawan yang dimilikinya, sementara untuk memperoleh karyawan yang tepat pada saat yang tepat tidaklah mudah dalam situasi yang beragam atau diversity (Manshor et al.,.. 2002:21). Keanekaragaman dapat dipahami sebagai suatu kondisi yang merujuk pada sejumlah perbedaan di antara individu yang disebabkan oleh faktor-faktor umur, ras, agama, functional specialty, profesi, jenis kelamin, asal daerah, gaya hidup, masa kerja dalam organisasi, kedudukan atau posisi jabatan, dan faktor lainnya (Mondy dan Noe, 2005:50). Para karyawan dalam organisasi terdiri atas para individu dengan karakteristik yang sangat beragam baik karakteristik kepribadian maupun perbedaan status geografisnya.

Karakteristik yang sangat spesifik melekat pada masing-masing individu tersebut menimbulkan adanya perbedaan perilaku. Dalam hal ini manajemen organisasi berperan penting untuk mewujudkan perilaku inovatif sesuai dengan yang diharapkan oleh organisasi (desired behavior) di antara para karyawannya. Perbedaan karakteristik yang terdapat pada masing-masing pribadi individu merupakan dasar bagi organisasi untuk memahami dan menganalisis sebab-sebab mengapa suatu perilaku dilakukan sementara perilaku lainnya tidak dilakukan oleh individu tertentu (Winardi, 2004: 195). Dengan demikian untuk mewujudkan perilaku inovatif sebagaimana yang diharapkan, dibutuhkan sebuah analisa bagaimana kebutuhan pelatihan yang sesuai.

\section{Faktor-Faktor Penyebab Perilaku Inovatif}

Asumsi yang mendasari pemikiran untuk mengkaitkan sikap dan perilaku dengan karakteristik individu merujuk pada kenyataan bahwa heterogenitas tenaga kerja yang berasal dari etnis dan karakteristik yang berbeda akan berdampak pada terbentuknya persepi, sikap dan perilaku yang berbeda pula, misalnya dalam bentuk perbedaan atau keanekaragaman tingkat motivasi dan kepuasan kerja diantara individu (Friday dan Friday, 2003). Oleh karena itu, faktor-faktor penyebab perilaku kerja dalam organisasi 
sama sekali tidak dapat dilepaskan dari ketiga aspek yang saling berkaitan yaitu faktor individual, faktor psikologikal, dan faktor organisasi (Winardi, 2004: 196).

Faktor-faktor individual yang menyebabkan terbentuknya perilaku terdiri dari sejumlah aspek yaitu kemampuan dan ketrampilan, latar belakang dan pengalaman interaksi sosial, serta aspek demografis. Sementara sikap individu dapat dilihat dalam bentuk misalnya kepuasan kerja, motivasi kerja dan identifikasi terhadap organisasi (Long, 2000: 91). Kepuasan kerja dalam hal ini merupakan sikap individu terhadap situasi organisasi, sedangkan motivasi kerja dapat didefinisikan sebagai sikap individu terhadap upaya pencapaian kinerja atau tujuan yang ditetapkan. Adapun identifikasi organisasi merupakan sikap individu yang mencakup tiga elemen terintegrasi yaitu kepekaan terhadap tujuan dan nilai bersama, kepekaan atau rasa memiliki, dan intensi atau keinginan untuk tetap bekerja (retain) dalam organisasi.

Dalam konteks pengembangan SDM, faktor-faktor organisasi ini merupakan metode intervensi sesuai dengan empat inti teori implementasi dalam proses perubahan (implementation theory) yang terdiri dari human processual intervention theory, technostructural intervention theory, sociotechnical systems (STS) designs, dan organization transformation change (Desimone et al,.. 2002: 569-571). Bahwa perilaku individu dapat terbentuk melalui sejumlah intervensi melalui pengalokasian sumber daya berdasarkan prinsip procedural justice sementara peran pimpinan sangat penting artinya dalam memodifikasi perilaku. Demikian pula dengan imbalan (rewards), perancangan struktur organisasi dan pekerjaan yang memainkan fungsi vital bagi terbentuknya perilaku individu.

\section{Bentuk-Bentuk Perilaku Inovatif}

Setiap upaya perbaikan dan peningkatan kompetensi melalui perilaku individu tidak terlepas dari kerangka pengembangan organisasi untuk mempersiapkan karyawan menghadapi tantangan-tantangan masa depan, yakni melalui pelatihan sebagai sarana dalam meningkatkan kemampuan individu untuk berperilaku inovatif terutama dalam kaitannya dengan upaya penyelesaian semua tugas dan pekerjaannya di masa-masa mendatang yang penuh dengan tuntutan karena terdapat perubahan teknologi dan arus globalisasi (Morris, 2004).

Diantara fungsi manajemen SDM yang paling penting dalam organisasi adalah mengelola perilaku kerja individu yang inovatif dalam rangka melaksanakan kewajibannya untuk membantu dalam pencapaian tujuan organisasi (Barney dan Griffin, 2000: 16). Sebagai akibat dari adanya perbedaan latar belakang dan pengalaman masing-masing individu, maka di dalam organisasi dapat dijumpai berbagai macam bentuk perilaku kerja. Perilaku kerja yang inovatif pada dasarnya bersifat sangat kompleks yang dipengaruhi oleh sejumlah variabel psikologis yakni diantaranya dalam bentuk persepsi, sikap, karakteristik pribadi, dan motivasi (Winardi, 2004: 197). 
Perilaku inovatif dari setiap individu dapat dianggap sebagai konsekuensi setelah munculnya sikap individu tertentu terhadap situasi organisasi yang menampakkan diri dalam berbagai bentuk dimana diantaranya terwujud seperti agresif, kreatif, independen, inisiatif, memiliki ketrampilan, kompeten dan berintegritas yang kesemuanya mengarah pada "creating new ideas and getting them to work" (Gaynor, 2002:16). Perilaku inovatif lebih jauh lagi menjadi pusat perhatian dalam kajian pengembangan individu untuk mendukung organisasi dalam rangka mendorong survival dan kemampuan bersaing secara berkelanjutan (Luecke, 2003:10). Perilaku yang inovatif (innovative behavior) dapat didefinisikan sebagai atribut yang melekat pada individu (Barker, 2002:2) yang "directed at the generation, introduction, an aplication of beneficial novelty at any organizational level (De Jong dan Kemp, 2003:11), mengindikasikan bahwa perilaku inovatif dipengaruhi oleh tujuh faktor determinan (penentu) yaitu job challenge, autonomy, strategic attention, supportive climate, external contacts, market differentiation, dan variation in demand. Perilaku inovatif bukanlah semata-mata dipengaruhi faktor bawaan atau internal. Perilaku inovatif dalam bekerja justru muncul manakala seorang karyawan menghadapi sejumlah tantangan dalam pekerjaannya, mendapat otonomi atau kewenangan yang luas dalam melaksanakan tugas dan tanggungjawabnya. Organisasi harus pula menyadari bahwa iklim yang mendukung aktivitas individu juga dapat mendorong untuk berinovasi.

Bagi industri kecil sepatu sebagai obyek penelitian ini, kinerja yang dicapai sangat bergantung pada perilaku kerja yang inovatif dari setiap karyawan produksi untuk menunjang pelaksanaan dan penyelesaian pekerjaannya. Praktek manajemen SDM dengan fokus pada individu memainkan peranan penting bagi perkembangan industri kecil (Skinner et at., ,... 2003;12). Secara tipologis, pencapaian kinerja industri kecil dapat diukur dari dua aspek yakni kinerja pada level organisasi yang meliputi ukuran-ukuran non-keuangan dan keuangan serta kinerja pada level individual yang meliputi peningkatan pertumbuhan jumlah karyawan dan pengembangan kompetensi dan personalnya (Abouzeedan dan M. Busler, 2004). Strategi pengelolaan SDM dengan titik tekan perhatian pada perilaku kerja inovatif dari karyawan merupakan sumber keberhasilan bagi kemajuan industri kecil (Edelman et al.,.. 2002). Berintegrasi dengan strategi organisasi yang sesuai dengan arah tuntutan dan perubahan lingkungan, perilaku inovatif individu mendorong percepatan pertumbuhan industri kecil untuk mencapai kinerja organisasi yang optimal (Beal, 2000). Perilaku kerja positif dalam bentuk inovasi (innovative behavior) bahkan menjadi bagian penting untuk mempersiapkan kemampuan daya saing internasional industri kecil di suatu negara tertentu (Tovstiga et al.,.. 2004). Dengan demikian pegembangan SDM melalui pelatihan pada industri kecil sepatu menjadi kepatutan yang harus dilakukan.

\section{Industri Kecil di Indonesia}

Di Indonesia industri kecil memegang peran vital dalam perekonomian untuk menyerap tenaga kerja, serta tumbuhnya motivasi dan pertumbuhan. Seperti halnya di negara lain, 
industri kecil di Indonesia menghadapi perubahan global yang menuntut kesiapan untuk menghadapi berbagai fenomena seperti persaingan usaha dan sebagainya. Kenyataan membuktikan bahwa industri kecil di Indonesia belum siap menghadapi tuntutan perubahan tersebut sehingga semua pihak perlu memikirkan secara serius untuk memperkuat program-program pengembangan industri kecil tersebut (Supriyono dan Setyawan, 2004: 45).

Upaya pembinaaan dan pengembangan industri kecil di Indonesia telah dan sedang diusahakan oleh beberapa lembaga pemerintah dan non-pemerintah, namun demikian permasalahan muncul ketika landasan konseptual untuk merumuskan makna industri kecil berbeda-beda menurut versi masing-masing instansi. Sebagai contoh Badan Pusat Statistik (BPS) merumuskan industri kecil (dengan istilah usaha kecil) difokuskan pada industri manufaktur berdasarkan serapan tenaga kerja yaitu untuk industri rumah tangga dan industri kecil menggunakan tenaga kerja antara 5 (lima) hingga 19 (sembilan belas) orang, untuk industri sedang atau menengah menggunakan tenaga kerja antara 20 (dua puluh) hingga 99 (sembilan puluh sembilan orang), dan untuk industri besar dengan tenaga kerja lebih dari 100 (seratus) orang.

Sementara itu Departemen Perindustrian dan Perdagangan membagi usaha kecil menjadi 2 (dua) kelompok yaitu industri kecil dan perdagangan kecil. Menurut instansi ini, yang disebut industri kecil adalah usaha industri yang memiliki investasi peralatan di bawah Rp 70.000.000 (tujuh puluh juta rupiah) dengan jumlah tenaga kerja di bawah 20 (dua puluh) orang dan memiliki aset perusahaan tidak lebih dari Rp 100.000.000 (seratus juta rupiah). Sementara yang dimaksudkan dengan perdagangan kecil adalah usaha yang bergerak di bidang perdagangan dan jasa komersil dengan modal kurang dari Rp 80.000.000 (delapan puluh juta rupiah).

Instansi pemerintah lainnya yaitu Departemen Keuangan dan Bank Indonesia menentukan industri kecil dengan kriteria lainnya. Menurut Departemen Keuangan kriteria industri kecil adalah suatu usaha yang memiliki nilai aset maksimal Rp 600.000.000 (enam ratus juta rupiah) di luar tanah dan bangunan atau memiliki omset maksimal Rp 600.000.000 (enam ratus juta rupiah) per tahun. Sedangkan kriteria industri kecil menurut Bank Indonesia adalah mempunyai aset maksimal Rp 600.000 .000 (enam ratus juta rupiah) di luar tanah dan bangunan dengan omset maksimal Rp 2.000.000.000 (dua milyar rupiah).

Di luar batasan kriteria industri kecil tersebut, terdapat pula lembaga lain yang menentukan pengertian definitif industri kecil. Kamar Dagang dan Industri (KADIN) Indonesia misalnya mendefinisikan industri kecil sebagai sektor usaha yang memiliki aset maksimal Rp 250.000.000 (dua ratus lima puluh juta rupiah) dengan jumlah tenaga kerja paling banyak 300 (tiga ratus) orang dan nilai penjualan di bawah Rp 100.000.000 (seratus juta rupiah). Instansi pemerintah lainnya yaitu Departemen Koperasi dan PKM 
menetapkan kriteria industri kecil yang sama dengan kriteria dari Bank Indonesia yaitu omset tidak melebihi Rp 2.000.000.000 (dua milyar rupiah) dengan kekayaan tidak lebih dari Rp 600.000.000 (enam ratus juta rupiah) tidak termasuk tanah dan bangunan.

Kriteria industri kecil yang tidak konsisten dari berbagai macam lembaga ini menyulitkan upaya pengembangan kebijakan yang tepat bagi industri kecil di Indonesia (Husaini et al.,.. 1996) sehingga pemerintah perlu memberi ketegasan untuk memberi batasan konseptual yang jelas bagi industri kecil. Untuk itu melalui Undang-undang (UU) Nomor 9 tahun 1995 tentang usaha kecil, pemerintah memberi batasan sebagai berikut:

1. Usaha kecil adalah kegiatan ekonomi rakyat yang berskala kecil yang meliputi usaha kecil informal dan usaha kecil tradisional. Usaha kecil informal adalah usaha yang belum terdaftar, belum tercatat, belum berbadan hukum misalnya petani penggarap, industri rumah tangga, pedagang asongan, pedagang keliling, pedagang kaki lima, pemulung,.

2. Usaha kecil tradisional adalah usaha yang menggunakan alat produksi sederhana yang telah digunakan secara turun-temurun dan/atau berkaitan dengan seni dan budaya. Kegiatan ekonomi rakyat yang berskala kecil dimiliki dan menghidupi sebagian besar rakyat.

3. Usaha menengah dan usaha besar adalah usaha nasional (milik negara atau swasta), usaha patungan dan usaha asing yang melakukan kegiatan ekonomi di Indonesia.

4. Usaha yang tangguh dan mandiri adalah usaha yang memilki daya saing tinggi dan memiliki kemampuan memecahkan masalah bertumpu pada kepercayaan dan kemampuan sendiiri.

Dengan pengertian tersebut dalam undang-undang ini juga ditentukan kriteria usaha kecil, yaitu:

1. Memiliki kekayaan bersih paling banyak Rp 200.000.000 (dua ratus juta rupiah) tidak termasuk tanah dan bangunan tempat usaha.

2. Memiliki hasil penjualan tahunan paling banyak Rp 1.000.000.000 (satu milyar rupiah).

3. Milik warga negara Indonesia.

4. Berdiri sendiri, bukan merupakan anak perusahaan atau cabang perusahaan yang dimiliki, dikuasai atau berafilisasi baik langsung maupun tidak langsung dengan usaha menengah dan besar.

5. Berbentuk badan usaha orang perorangan, tidak berbadan hukum, atau berbadan hukum, termasuk koperasi.

Kriteria tersebut mendapat tambahan dengan ketentuan bahwa nilai nominal dapat diubah sesuai dengan perkembangan perekonomian yang diatur dengan Peraturan Pemerintah. Dengan merujuk pada UU 9/1995 tersebut beberapa instansi pemerintah telah mengadakan penyesuaian untuk mencapai kesamaan cara pandang. Departemen 
Perindustrian dan Perdagangan misalnya, melalui Surat Keputusan (SK) Nomor 254/MPP/7/1997 menetapan kriteria industri kecil dan perdagangan kecil sebagai berikut:

1. Industri kecil adalah industri yang memiliki nilai investasi perusahaan sampai dengan Rp 200.000.000 (dua ratus juta rupiah) tidak termasuk tanah dan bangunan dengan pemilik warga negara Indonesia.

2. Usaha Dagang Kecil adalah usaha di bidang perdagangan, jasa komersial yang memiliki nilai investasi perusahaan sampai dengan Rp 200.000.000 (dua ratus juta rupiah) tidak termasuk tanah dan bangunan dengan pemilik warga negara Indonesia.

\section{METODE PENELITIAN}

\section{Rancangan Penyusunan Model}

Rancangan dalam penyusunan model ini dilakukan dengan paradigma sistem (input, proses, output). Penyusunan Training Needs Analysis dalam analisis kebutuhan, yaitu dengan mendokumentasikan permasalahan, identifikasi masalah, merencanakan kebutuhan analisis, melakukan analisis kebutuhan, dan melaporkan hasil temuan akhir.

\section{Teknik Penentuan Informan}

Penelitian ini adalah sebuah penelitian deskriptif kualitatif dan membutuhkan informan untuk mencari fakta terhadap fenomena yang terjadi. Informan adalah orang-dalam pada latar penelitian dan dimanfaatkan untuk memberikan informasi tentang situasi dan kondisi latar penelitian, jadi ia harus mempunyai banyak pengalaman tentang latar penelitian (Moleong, 1996:132). Informan dalam penelitian ini adalah perwakilan pemilik usaha, perwakilan mandor produksi, dan perwakilan dari Disperindag Jatim.

\section{Analisis Data}

Data yang sudah diolah kemudian dianalisis melalui Focus Group Discussion (FGD) dan disajikan secara deskriptif kualitatif. FGD dilakukan untuk menguji keabsahan data melalui konfirmasi hasil model yang akan disusun. Hasil FGD menjadi acuan dalam penyusunan model training needs analysis (TNA) untuk membetuk perilaku inovatif SDM industri kecil di Jawa Timur.

\section{Training Needs Analysis}

Beberapa temuan yang menyebabkan kurangnya perilaku inovatif dan menyebabkan turunnya kinerja penjualan yaitu antara lain:

1. Adanya inovasi produk yang cepat sehingga pekerja industri sepatu membutuhkan waktu untuk lebih mengenal produk-produk baru sehingga diharapkan oleh perusahaan adalah pekerja dapat mengikuti setiap perkembangan produk baru.

2. Kemampuan pengelolaan pengetahuan yang kurang, disebabkan adanya faktor pendidikan dan kemampuan masing-masing pekerja dalam mencari informasi keberadaan produk baru. 
3. Pekerja tidak mempunyai konsep yang jelas tentang apa yang harus ia lakukan (motivasi, komitmen) yang berhubungan dengan kreativitas serta inovasi produk baru, karena mereka terpacu pada perintah perusahaan mengenai pengembangan model sepatu yang baru.

Ketiga masalah di atas diidentifikasikan sebagai permasalahan yang sebenarnya yang menyebabkan degradasi skill dan akhirnya akan mempengaruhi kinerja perusahaan. Permasalahan tersebut diakui oleh informan, yaitu salah satu informan menyatakan bahwa persoalan yang sebenarnya dan berkaitan dengan produksi sepatu ialah kemampuan karyawan produksi dalam pengembangan desain. Mereka hanya dapat menunggu perintah dari mandor dan apabila terdapat ketidakpahaman atas model, mereka tidak mempunyai inisiatif untuk bertanya. Hal ini disebabkan karena pendidikan mereka yang rendah, ketidaktahuan akan teknologi, dan informasi pembaharuan produk yang kurang.

Industri sepatu yang mengalami pertumbuhan yang pesat, dalam hal menghasilkan produk baru. Percepatan model, desain, dan berbagai inovasi produk sepatu ini, tidak diikuti oleh perkembangan kecepatan kemampuan karyawan produksi dalam merespon perubahan keinginan pasar. Adanya tekanan pasar yang kuat, menyebabkan bagian produksi, sub bagian desain model sepatu harus bekerja keras mencari tahu model terbaru, dan mampu mengkontruksikan model tersebut ke semua karyawan produksi. Tetapi hal tersebut belum terjadi optimal, kondisi ini didukung oleh pernyataan informan, yaitu ia menyatakan bahwa pasar menekan kuat untuk berinovasi, tetapi karyawan produksi belum mampu mengikuti keinginan pasar. Mereka hanya bisa mengembangkan desain produk, inisiatif untuk itu mereka belum bisa. Dan mereka lambat dalam memahami produk baru yang akan digarap. Padahal, ketika ada model desain baru, maka prosedur dan pengerjaan serta jadwal pengerjaan akan berubah mengikuti desain baru tersebut. Hal ini yang belum mereka kuasai dengan baik.

Berbagai persoalan di atas, hanya sebagian persoalan kecil. Ada persoalan yang lebih penting dan menjadi hal penting untuk diselesaikan, yaitu persoalan motivasi dan komitmen. Komitmen dan motivasi yang berhubungan dengan kreativitas/inovasi produk. Kemampuan karyawan produksi dalam berkreasi sangat dipengaruhi oleh komitmen mereka dan motivasi mereka dalam menghasilkan karya terbaik. Faktor-faktor individual yang menyebabkan terbentuknya perilaku inovatif yang ditunjukkan dari hasil diskusi dengan informan, yaitu terdiri dari sejumlah aspek kemampuan dan ketrampilan, latar belakang dan pengalaman interaksi sosial, serta aspek komitmen.

Seorang informan menyatakan bahwa selama ini memang belum disediakan bentuk pelatihan tentang menumbuhkan kreativitas dan inovasi produk. Pelatihan yang ada hanya untuk para pemilik, manajer dan hal itu hanya tentang manajemen usaha atau pelatihan yang berhubungan dengan pengelolaan keuangan, sedangkan pelatihan khusus 
untuk bagian produksi, belum pernah dilakukan. Keseriusan perusahaan dalam hal pengembangan produkpun, belum diikuti melalui bagian penelitian dan pengembangan produk. Karena mereka hanyalah industri kecil, dan masih berorientasi pada omset produk, belum berorientasi pada penciptaan produk sendiri. Selama ini penciptaan model, desain sepatu hanya mengambil dari luar, yaitu dari internet, dari majalah, dan hanya mengandalkan pemesanan dari pelanggan, sehingga kondisi ini membuat karyawan produksi tidak mampu berinovasi sendiri, dan akhirnya kemampuan mereka dalam berperilaku inovatif kurang.

Kebutuhan peningkatan skill dapat melalui dua level skill yang diperbaiki yaitu compilation (lower level) dan automaticity (higher level) (Blanchard dan Thacker, 2004: 8). Dua level ini merefleksikan perbedaan dalam tingkat kecakapan seseorang, dimana skill menjadi sebuah rutinitas atau otomatis. Ketika seseorang belajar dari bagian skill atau hanya mempelajari apa yang baru ia terima, dia termasuk dalam level compilation. Ketika seseorang dihadapkan pada pekerjaan yang membutuhkan skill tertentu maka apabila ia memerlukan sebuah pemahaman dulu sebelum ia melakukanya maka ia berada pada level compilation tetapi ia yang berada pada level automaticity maka ia akan secara otomatis melakukannya. Dan karyawan produksi berada pada kedua level skill tersebut. Untuk itu diperlukan usaha pelatihan kepada karyawan dalam usaha mempelajari keahlian baru, meningkatkan kinerja, dan tumbuh dalam kinerja di masa depan serta perbaikan skill. Sebagai suatu proses, pelatihan membawa suatu perubahan dalam pembelajaran tindakan (aksi), pelatihan adalah sebuah peran Human Resouces Development (HRD) yang efektif karena ia memusatkan pada masalah pekerja (Sofo, 2003:170).

Beberapa kondisi persoalan mengenai skill karyawan produksi, perlu dianalisis kebutuhan skill. Skill needed timbul karena perusahaan mempersiapkan orang-orangnya untuk sebuah perubahan (new roles) dan pemenuhan pengembangan potensi yang tinggi dari karyawan (Siauw, 2002:22), karena perusahaan berfokus pada pengembangan skill yang dipunyai karyawannya.

Dalam pengembangan skill karyawan produksi meliputi perbaikan kinerja dan pengembangan skill tersebut digunakan untuk mengidentifikasikan kebutuhan pelatihan karena perusahaan menentukan target atau standart yang harus dipenuhi dari setiap pekerjaan. Untuk menutupi kesenjangan skill tersebut dibutuhkan sebuah proses analisis. Skill gap analisis merupakan proses untuk menentukan pelatihan apa yang diperlukan dari karyawan dalam hubungannya dengan komponen-komponen tugas/pekerjaan yang identifikasikan untuk sebuah pelatihan (Halim, 2004: 51).

Uraian beberapa persoalan di atas, menjadi bahan utama dalam menganalisa kebutuhan pelatihan karyawan produksi, dan disajikan dalam tabel 1 berikut ini: 
Tabel 1

Penyusunan Training Needs Analysis

\begin{tabular}{|c|c|c|}
\hline No & $\begin{array}{l}\text { Langkah- } \\
\text { langkah }\end{array}$ & Uraian \\
\hline 1 & $\begin{array}{l}\text { Dokumentasi } \\
\text { Masalah }\end{array}$ & $\begin{array}{l}\text { Defisiensi skill karena karyawan produksi tidak dapat bekerja secepat } \\
\text { perkembangan produk }\end{array}$ \\
\hline 2 & $\begin{array}{l}\text { Investigasi } \\
\text { Masalah }\end{array}$ & $\begin{array}{l}\text { Adanya inovasi produk yang cepat, pengelolaan pengetahuan produk } \\
\text { yang kurang (karena keterampilan dan pendidikan rendah), } \\
\text { ketidakadaan konsep pemahaman inovasi produk (disebabkan } \\
\text { komitmen dan motivasi berkreasi kurang) }\end{array}$ \\
\hline 3 & $\begin{array}{l}\text { Merencanakan } \\
\text { kebutuhan } \\
\text { Analisis }\end{array}$ & $\begin{array}{l}\text { Analisis dilakukan melalui : } \\
\text { 1. Analisis organisasional: bahwa perusahaan yang bergerak dalam } \\
\text { industri sepatu membutuhkan kompetensi produksi lebih, yaitu } \\
\text { kemampuan bergerak secepat perkembangan produk baru. } \\
\text { 2. Analisis jabatan: untuk posisi karyawan produksi dibutuhkan } \\
\text { skill: product knowledge/pengembangan desain, skill perencanaan } \\
\text { kerja, dan skill pengerjaan sepatu yang efektif } \\
\text { 3. Analisis Person: skill yang ditunjukkan karyawan produksi yaitu } \\
\text { pengelolaan pengetahuan produk baru kurang, pemahaman } \\
\text { inovasi produk kurang, motivasi, dan komitmen untuk berkreasi } \\
\text { kurang. }\end{array}$ \\
\hline 4 & $\begin{array}{l}\text { Pemilihan } \\
\text { Teknik Analisis }\end{array}$ & $\begin{array}{l}\text { Teknik needs assessment: } \\
\text { 1. optimal (menganalisis skill needed: kemampuan inovatif } \\
\text { karyawan produksi) } \\
\text { 2. actual (menganalisis actual skill : karyawan produksi belum } \\
\text { mempunyai kemampuan inovatif) } \\
\text { 3. feeling (menganalisis beberapa pendapat mandor, pemilik usaha } \\
\text { dan Disperindag) } \\
\text { 4. causes (menganalisis tentang penyebab skill inovatif kurang yaitu } \\
\text { disebabkan karena paksaan pasar, pengembangan desain yang } \\
\text { harus diikuti, pengerjaan atas model sepatu baru, perubahan } \\
\text { teknologi, komitmen dan motivasi berkreasi, dan keputusan untuk } \\
\text { melakukan pelatihan serta menyusun berbagai upaya peningkatan } \\
\text { skill inovatif melalui selain pelatihan) }\end{array}$ \\
\hline 5 & $\begin{array}{l}\text { Melakukan } \\
\text { analisis }\end{array}$ & $\begin{array}{l}\text { Melakukan diskusi dan indepth interview dengan perwakilan pemilik } \\
\text { usaha, perwakilan mandor dan Disperindag }\end{array}$ \\
\hline 6 & Analisis data & Focus Group Discussion \\
\hline 7 & $\begin{array}{l}\text { Pelaporan } \\
\text { temuan }\end{array}$ & $\begin{array}{l}\text { Temuan: karyawan produksi membutuhkan pelatihan yang } \\
\text { berhubungan dengan perbaikan kompetensi inovatif yaitu melalui } \\
\text { pelatihan product knowledge/pengembangan desain, perencanaan } \\
\text { kerja, pengerjaan kerja yang efektif, peningkatan komitmen dan } \\
\text { motivasi. }\end{array}$ \\
\hline
\end{tabular}

Sumber: hasil FGD dengan Pemilik Usaha, Mandor dan Disperindag, 2008. 


\section{ANALISIS DAN PEMBAHASAN}

\section{Penyusunan Model Training Needs Analysis}

Setelah dilakukan analisis kebutuhan selanjutnya adalah menyusun temuan-temuan dari analisis tersebut ke dalam sebuah model, yaitu:

1. Trigger

Trigger (pemicu kejadian) yaitu diperoleh dari hasil temuan TNA yang sudah dilakukan bahwa terjadi defisiensi skill, disebabkan karena perbedaan karateristik individu yang berbeda-beda, pendidikan karyawan produksi yang rendah, paksaan pasar untuk berkreasi, perbedaan pemahaman atas konsep desain baru, komitmen dan motivasi karyawan yang kurang, dan gaya kerja di masing-masing individu/pekerja yang berbeda.

2. Input

Input atau masukan dari model ini yaitu diperolehnya beberapa data/informasi yang diperoleh dari 3 analisis yaitu: a) Analisis organisasional. Analisis ini berhubungan dengan kebutuhan organisasi/perusahaan secara keseluruhan diikuti dengan identifikasi bagaimana pelatihan dapat dieksploitasi sedemikian rupa untuk mencapai tujuan dari perusahaan. Dari analisis ini diperoleh bahwa perusahaan membutuhkan peningkatan skill karyawan produksi dalam hal berkreasi, tuntutan pasar yang bergerak cepat membuat perusahaan harus bergerak cepat mengikuti perubahan tersebut dan memenuhi tuntutan tersebut dengan cara peningkatan kompetensi karyawan produksi, b) Analisis Jabatan/ tugas. Proses analisis tugas ini telah dilakukan pada pengelolahan data dan pada analisis kebutuhan TNA telah ditemukan bahwa untuk posisi produksi dibutuhkan perilaku inovatif, meliputi: skill management knowledge product, skill pemahaman produk, skill perencanaan kerja, kemampuan pengerjaan yang efektif, c) Analisis Personal. Analisis ini digunakan untuk menemukan skill yang dipunyai oleh bagian produksi, maka analisis personal ini ditemukan bahwa skillnya kurang dalam berkreasi, pemahaman produc knowledge/pengembangan desain, perencanaan kerja, pengambilan keputusan, motivasi, dan komitmen untuk berkreasi yang kurang.

3. Proses

Temuan dari analisis TNA yang telah disusun yaitu pekerja produksi kurang dalam berperilaku inovatif.

4. Output

Output dari proses dan beberapa input yaitu training needs dan non training needs. Permasalahan pokok yang ada adalah tidak terpenuhinya skill needed akan actual skill. Temuan-temuan dalam TNA yang ada mengidentifikasikan bahwa terdapat beberapa persoalan yang harus diselesaikan dengan training tetapi ada juga yang tidak diselesaikan dengan training. 
Kebutuhan pelatihan, meliputi:

1. Pelatihan peningkatan product knowledge/pengembangan desain

Kebutuhan pelatihan peningkatan product knowledge/pengembangan desaine diberikan untuk meningkatkan kemampuan dalam hal menciptakan hal-hal baru, sesuai dengan ide dan pengetahuan produk. Pelatihan ini bertujuan agar kemampuan berkreasi dalam hal model, jenis dan tren sepatu dapat mengimbangi perkembangan produk di pasaran. Pengetahuan produk diperlukan dalam hal inovasi produk baru.

2. Pelatihan Kemampuan Penguasaan Teknologi

Pelatihan ini dibutuhkan karena pekerja produksi kurang dalam penguasaan teknologi. Perubahan dan perkembangan teknologi yang cepat menjadi tuntutan bagi karyawan produksi untuk mengikuti perubahan tersebut. Berhubungan juga dalam hal koordinasi, diskusi dan memberikan masukan atas ide serta gagasan terhadap produk baru melalui perlakuan teknologi yang canggih.

3. Pelatihan meningkatkan pemahaman perencanaan kerja, sistem kerja, dan pengambilan keputusan kerja

Pelatihan ini dibutuhkan karena pekerja produksi selama ini belum mampu memahami perencanaan kerja, sistem kerja, dan mengambil keputusan atas ide/gagasan yang mereka miliki. Padahal untuk pekerja produksi, mereka dituntut untuk memiliki kreativitas yang lebih, dan mereka di tuntut untuk cermat dalam pengambilan keputusan yang berhubungan dengan detail produk yang ia hasilkan.

4. Pelatihan meningkatkan kemampuan Personable

Selain pelatihan yang dibutuhkan untuk meningkatkan skill, pelatihan yang lain adalah untuk pelatihan yang berhubungan dengan personalitas. Kepribadian membuat pekerja lebih percaya diri tinggi dan menumbuhkan semangat bekerja. Motivasi juga sangat diperlukan dalam menyelesaikan tugas-tugasnya, sehingga menumbuhkan kreativitas dalam bekerja.

Beberapa kebutuhan pelatihan tersebut diyakini mampu menjawab persoalan atas kebutuhan perilaku inovatif karyawan produksi. Pelatihan merupakan sebuah proses pembelajaran, dan dilakukan dalam tahapan tertentu, dilakukan dalam waktu tertentu, dan yang paling ditakutkan adalah hasil pelatihan akan tidak berlangsung lama. Persoalan tersebut menjadi persoalan baru, oleh karena itu diperlukan sebuah kebiasaan atau menciptakan budaya pembelajaran di tiap waktu selama proses produksi berlangsung. Proses pembelajaran tersebut akan terwujud sebagai aksi perbaikan kompetensi, dan akhirnya akan berujung pada perbaikan kinerja. Pelatihan yang sebenarnya ialah pelatihan yang berkelanjutan, artinya pelatihan tersebut harus senantiasa dievaluasi, dianalisis, dan menyusun kebutuhan pelatihan yang baru. Dan ketika pelatihan didesain melalui analisis kebutuhan, maka diyakini pelatihan tersebut menggambarkan kebutuhan yang sebenarnya. 
Kebutuhan atas pelatihan tersebut, disajikan dalam tabel 2 berikut ini:

Tabel 2

Kebutuhan Pelatihan Karyawan Produksi

\begin{tabular}{|c|c|c|c|}
\hline No & $\begin{array}{c}\text { Kebutuhan } \\
\text { Kompetensi } \\
\text { Pekerjaan } \\
\end{array}$ & $\begin{array}{c}\text { Kompetensi yang } \\
\text { Ditunjukkan Sekarang }\end{array}$ & Kebutuhan Pelatihan \\
\hline 1 & $\begin{array}{l}\text { Pemahaman dan } \\
\text { kemampuan untuk } \\
\text { mengikuti/ menjawab } \\
\text { tuntutan perubahan } \\
\text { pasar atas produk baru }\end{array}$ & $\begin{array}{l}\text { Karyawan produksi belum } \\
\text { mampu memahami/ } \\
\text { mengikuti perkembangan } \\
\text { desain baru }\end{array}$ & $\begin{array}{l}\text { Pelatihan peningkatan } \\
\text { skill product knowledgel } \\
\text { pengembangan desain, } \\
\text { manajemen atas } \\
\text { pengelolaan pengetahuan } \\
\text { produk baru }\end{array}$ \\
\hline 2 & $\begin{array}{l}\text { Kemampuan } \\
\text { perencanaan kerja }\end{array}$ & $\begin{array}{l}\text { Karyawan produksi belum } \\
\text { mampu melakukan } \\
\text { perencanaan kerja sesuai } \\
\text { penjadwalan, proses } \\
\text { produksi pada produk baru }\end{array}$ & $\begin{array}{l}\text { Pelatihan peningkatan } \\
\text { skill perencanaan kerja }\end{array}$ \\
\hline 3 & $\begin{array}{l}\text { Kemampuan } \\
\text { pengerjaan kerja yang } \\
\text { efektif }\end{array}$ & $\begin{array}{l}\text { Karyawan produksi belum } \\
\text { mampu mengerjakan } \\
\text { produksinya dengan efektif }\end{array}$ & $\begin{array}{l}\text { Pelatihan peningkatan } \\
\text { skill pengerjaan efektif } \\
\text { kerja }\end{array}$ \\
\hline 4 & $\begin{array}{l}\text { Kemampuan } \\
\text { penguasaan teknologi }\end{array}$ & $\begin{array}{l}\text { Karyawan produksi belum } \\
\text { mampu menguasai } \\
\text { teknologi yang dibutuhkan }\end{array}$ & $\begin{array}{l}\text { Pelatihan penguasaan } \\
\text { teknologi melalui } \\
\text { pengenalan, pemahaman } \\
\text { atas program-program } \\
\text { baru }\end{array}$ \\
\hline 5 & $\begin{array}{l}\text { Sikap komitmen dan } \\
\text { motivasi untuk selalu } \\
\text { berkreasi }\end{array}$ & $\begin{array}{l}\text { Karyawan produksi belum } \\
\text { termotivasi dan } \\
\text { berkomitmen untuk selalu } \\
\text { kreatif dan inovatif }\end{array}$ & $\begin{array}{l}\text { Pelatihan personable, } \\
\text { meliputi peningkatan } \\
\text { komitmen dan motivasi }\end{array}$ \\
\hline
\end{tabular}

Ada beberapa hal yang harus dipenuhi oleh perusahaan dalam upaya meningkatkan perilaku inovatif selain melakukan pelatihan (non training needs), yaitu:

1. Untuk menyamakan persepsi terhadap visi, misi, dan tujuan perusahaan yang berhubungan dengan perbaikan kualitas produki, maka perusahaan melakukan pendekatan persuasif dengan karyawan produksi, menyediakan kebutuhan yang diiinginkan karyawan, dan menciptakan lingkungan kerja yang kondusif.

2. Perusahaan memperbaiki konsep perkembangan produk, ini dilakukan dalam membahas setiap perkembangan produk yang dihasilkan dengan produk di pasaran, 
produk paling baru, dan paling digemari. Perbaikan konsep ini melalui pertemuan tersendiri yang membahas perkembangan produk baru yang mereka hasilkan. Perubahan konsep kerja dan membutuhkan bentuk manajemen kerja yang baru.

3. Perusahaan melakukan perbaikan dalam hal research dan pengembangannya, karena melalui penelitian dan pengembangan tersebut perusahaan mengetahui semua produk baru dan posisi produk yang telah diproduksi oleh perusahaannya di mata konsumen.

4. Perusahaan menyusun kerja baru dan membentuk budaya kerja baru melalui pembiasaan kerja kreatif, memberikan reward, bonus pada karyawan yang kreatif mungkin menjadi salah satu alternatif menumbuhkan motivasi dan komitmen dalam berkreasi.

Perilaku inovatif memerlukan sebuah komitmen pekerja pada organisasi atau perusahaan tempat ia bekerja, komitmen ini mencakup tiga bentuk sikap yaitu: (1) perasaan manunggal dengan tujuan organisasi, (2) perasaan terlibat dalam tugas dan kewajiban keorganisasian, dan (3) perasaan setia kepada organisasi. Sikap yang demikian ini terbentuk karena adanya nilai investasi karyawan dalam organisasi seperti senioritas dan keuntungan yang menyebabkan munculnya pandangan bahwa jika keluar dari organisasi akan mengalami banyak kerugian (Allen dan Meyer, 1990:13). Ketiga sikap tersebut juga merupakan hasil temuan bahwa pekerja produksi industri sepatu kurang berperilaku inovatif dikarenakan mereka belum mempunyai perasaan yang kuat ketika terlibat dalam pekerjaan yang membutuhkan kreativitas tinggi, padahal kreativitas akan timbul tanpa paksaan.

Perilaku inovatif dari setiap individu yang bekerja dalam suatu organisasi/perusahaan sepatu tentu saja bersifat positif, memiliki dampak yang positif pula sifatnya bagi pencapaian kinerja individual maupun organisasi. Bagi industri kecil sebagai obyek penelitian ini, kinerja yang dicapai sangat bergantung pada perilaku kerja yang inovatif dari setiap karyawan untuk menunjang pelaksanaan dan penyelesaian pekerjaannya. Manajemen SDM dalam prakteknya membutuhkan upaya yang fokus pada pekerja produksi dan mereka memainkan peranan penting bagi perkembangan industri kecil Secara tipologis, pencapaian kinerja industri kecil dapat diukur dari dua aspek yakni kinerja pada level organisasi yang meliputi ukuran-ukuran non-keuangan dan keuangan serta kinerja pada level individual yang meliputi peningkatan pertumbuhan jumlah karyawan dan pengembangan kompetensi dan personalnya (Abouzeedan dan Busler, 2004:18).

Strategi pengelolaan SDM dengan titik tekan perhatian pada perilaku kerja inovatif dari karyawan merupakan sumber keberhasilan bagi kemajuan industri kecil. Berintegrasi dengan strategi organisasi yang sesuai dengan arah tuntutan dan perubahan lingkungan, perilaku inovatif individu mendorong percepatan pertumbuhan industri kecil untuk mencapai kinerja organisasi yang optimal (Beal, 2000: 585). Peranan strategi perusahaan dalam membangun perilaku inovatif pekerja produksi memiliki makna penting bagi 
penciptaan budaya yang bertujuan untuk peningkatan daya saing dan keunggulan kompetitif. Strategi tersebut dimulai dengan perbaikan perilaku/kinerja melalui pelatihan. Sementara itu menurut Vermeulen (2004), konsep inovasi memiliki banyak makna yang merujuk pada berbagai pengertian yaitu sebagai proses atau perilaku yang berkaitan dengan terciptanya produk baru dalam organisasi.

Perbaikan kinerja atas perilaku inovatif tentu juga dipengaruhi oleh usia pekerja, karakteristik pekerja, pembelajaran yang ia temui (pembelajaran dapat diperoleh melalui pelatihan), kondisi ini didukung oleh Hult (2002:28) yang menekankan pentingnya aspek karakteristik individu yang terdiri atas sifat-sifat kewirausahaan, umur, pembelajaran dalam membentuk perilaku inovatif (innovativeness). Motivasi juga menjadi temuan penting, mengapa pekerja kurang berperilaku inovatif. Motivasi ini menjadi pemicu individu dalam bersikap dan berperilaku, temuan ini didukung oleh Blau (1994:254) yang menyatakan bahwa teori pertukaran sosial menjelaskan adanya proses motivasi dibalik sikap dan perilaku yang saling bergantian atau bertukar (exchanged) diantara para individu. Proses motivasi dalam teori pertukaran sosial dapat digunakan untuk menjelaskan keterkaitan antara persepsi dan sikap individu terhadap situasi organisasi yang berlanjut dengan terbentuknya perilaku kerja dalam organisasi (Whitener, 2001:213).

Tujuan akhir penjelasan perilaku berdasar teori pertukaran sosial adalah mengakui adanya kondisi dimana para individu merasa berkewajiban membalas (to reciprocate) jika mereka memperoleh keuntungan (benefits) dari tindakan organisasi dan individu lainnya (Haar dan Spell, 2004). Dalam konteks hubungan seperti ini teori pertukaran sosial digunakan sebagai pijakan untuk menguraikan penjelasan bahwa komitmen organisasi merupakan hasil dari persepsi individual terhadap kondisi lingkungan kerja yang sifatnya suportif (mendukung) sehingga melahirkan perilaku tertentu yang sejalan dengan norma organisasi. budaya organisasi yang berkembang dalam suatu organisasi tidak dapat terlepas dari dinamika situasi unsur-unsur internal dan eksternal organisasi. Unsur-unsur internal organisasi yang turut membentuk budaya organisasi diantaranya adalah management style dan proses pengambilan keputusan.

Sementara unsur-unsur eksternal diantaranya adalah national culture yang memiliki powerful influence terutama pada intepretasi, pemahaman, dan penilaian individu terhadap kebijakan dan strategi yang berlaku dalam organisasinya (Strandholm, Kumar, dan Subramaniam, 2004: 57). Perilaku inovatif pekerja industri kecil sepatu akan menjadi pembiasaan dan akan membentuk budaya, yaitu yang dipengaruhi oleh unsur internal (pembelajaran yang ditampilkan dalam pelatihan). Budaya perilaku inovatif nantinya akan menciptakan nilai khas dan berkembang dalam perusahaan dengan implikasi loyalitas dan perbaikan kinerja. 


\section{SIMPULAN}

Hasil penelitian ini menemukan sebuah model Training Needs Analysis (TNA) dalam sebuah sistem (input, proses, dan output). Model TNA yang telah disusun termasuk dalam jenis TNA reaktif yaitu sebagai berikut:

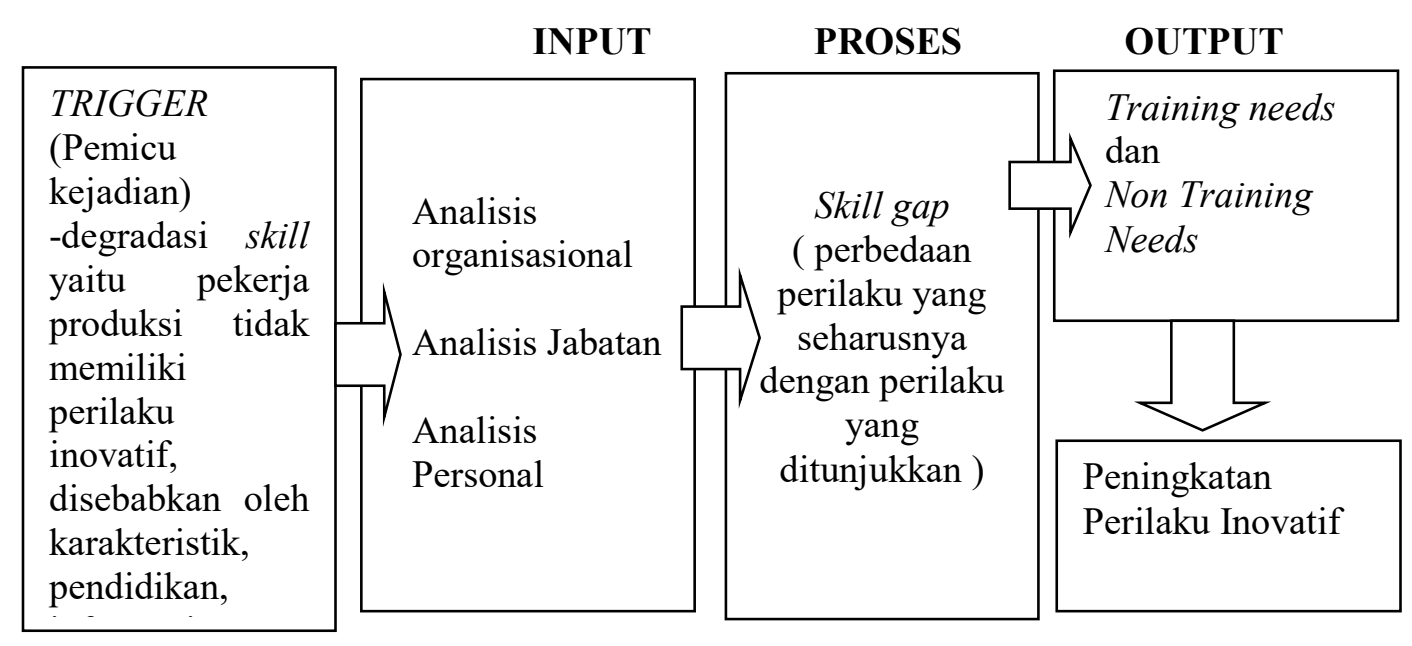

\section{Gambar 1}

Model Training Needs Analysis dalam Membentuk Perilaku Inovatif

Gambar di atas merupakan model TNA reaktif untuk membentuk perilaku inovatif pekerja produksi pada industri sepatu. Input terdiri atas analisis organisasional (analisis organisasi, job design, kinerja, prosedur kerja), analisis tugas yaitu analisis skill needed dan analisis personal untuk menemukan actual skill, proses mengidentifikasikan penyebab skill gap dan outputnya: training needs dan non training needs. Model direkomendasikan untuk meningkatkan perilaku inovatif karyawan produksi.

\section{IMPLIKASI DAN KETERBATASAN}

\section{Implikasi}

Hasil penelitian ini menemukan model training needs yang diyakini mampu untuk menjawab persoalan tentang perilaku inovatif pekerja produksi. Model menunjukkan bahwa perilaku inovatif mampu ditumbuhkan melalui bentuk pelatihan dan tidak melalui pelatihan. Model tersebut dapat diimplikasikan pada persoalan yang sama dan menjadi input dalam menyusun design pelatihan. 


\section{Keterbatasan}

Keterbatasan penelitian ini:

1. Keterbatasan penelitian ini hanya terletak pada fenomena permasalahan skill berperilaku inovatif pekerja produksi industri kecil sepatu sehingga direkomendasikan pada penelitian selanjutnya untuk diperluas pada unit kerja lain.

2. Keterbatasan pada penelitian ini juga terletak pada temuan akhir yaitu hanya sebatas penemuan model tanpa adanya analisis biaya dan design pelatihan. Diharapkan untuk penelitian selanjutnya memasukkan analisis biaya dan design pelatihan yang merupakan fase selanjutnya dalam melakukan pelatihan.

\section{DAFTAR PUSTAKA}

Abouzeedan, A., and M. Busler. 2004. Typology analysis of performance models of small and medium-size enterprises (SMES). Journal of International Enterpreneurship. Vol 2(2): 155-177.

Allen, N.J., dan J.P. Meyer. 1990. The measurement and antecedent of affective, continuance, and normative commitment to the organization. Journal of Occupational Psychology. Vol 63(1): 1-18.

Barker, A., 2002. The alchemy of innovation: perspectives from the leaing edge. London, Spiro Press.

Barney, J.B. dan Griffin, R.W. 2000, Management of Organizations: Strategy, Structure, \& Behavior, Boston, Houghton Mfifflin Company.

Blanchard NP dan Thacker JW. 2004. Efective Training: System, Strategies, and Practices. Second Edition. Pearson Education, Inc. New Jersey.

Beal, R.M. 2000. Competing effectively: environmental scanning, competitive strategy, and organizational performance in small manufacturing firms. Journal of Small Business Management. Vol 38(1): 27-48.

Blau, G.J. 1994. Using a person-environment fit model to predict job involvement and organizational commitment. Journal of Vocational Behavior. Vol 30(3): 240-257.

Desimone. 2002. Human resource development (3rd ed.). Fort Worth, Harcourt College Publishers. 
De Jong, J.P.J., \& R.Kemp. 2003. Determinants of co-workers' innovative behaviour: an investigation into knowledge intensive service. International Journal of Innovation Management. Vol 7 (2): 189-212.

Dinas Perindustrian dan Perdagangan Propinsi Jawa Timur. 2002. Laporan Identifikasi Potensi Sentra Industri kecil Sepatu. Proyek Peningkatan dan Pengembangan Usaha, Kualitas SDM dan Penguatan Struktur Industri, Seksi Penataan Kawasan Industri Sub Dinas Bina Usaha.

D’Netto, B., dan Sohal, A.S. 1999. Human resource practices and workforce diversity: an empirical assessment. International Journal of Manpower. Vol 20(8): 530-547.

Edelman. 2002. The impact of human and organizational resources on small firm strategy. Journal of Small Business and Enterprise Development. Vol 9 (3): 236244.

Friday, S.S., dan E. Friday. 2003. Racioethnic perceptions of job characteristics and job satisfaction. Journal of Management Development. Vol 22 (5): 426-442.

Gaynor, G.H. 2002. Innovation by design. New York, American Managemen Association.

Halim, Abdul. 2004. Training And Profesional Development. Gradute Training Institute: Bangladesh.

Haar, J.M., dan C.S. Spell. 2004. Programme knowledge and value of work-family practices and organizational commitment. International Journal of Human Resource Management. Vol 15 (6): 1040-1055.

Hult, G.T.M., 2002. Cultural competitiveness in global sourcing. Industrial Marketing Management.

Husaini, M., S. Hardjosoekarto, H., Nurasa, \& T. Mariman. 1996. Smal scale enterprises development in Indonesia dalam M. Pangestu (editor). Small- scale business development and competition policy. Jakarta, CSIS.

Irianto, Jusuf, 2001. Prinsip-prinsip Dasar Manajemen Pelatihan: Dari Analisis Kebutuhan Sampai Evaluasi Program Pelatihan. Insan Cendekia. Surabaya.

Kompas. 2005. Pemerintah dinilai menghambat INDUSTRI KECIL: terpukul kenaikan harga BBM dan perizinan, Kompas, 06/04/05. 
Luecke, R. 2003. Managing Creativity and Innovation. Boston, Harvard Business School Press.

Long, R.J. 2000. Compensation in Canada: strategy, practice, and issues. Toronto, International Thomson Publishing Company.

Mangkunegara, Anwar Prabu. 2003. Perencanaan dan Pengembangan SDM. PT. Refika Aditama. Bandung.

Manshor, A.T., M. Jusoh, \& M. Simun. 2002. Diversity factors and preferential treatments in selecting employees. Journal of Management Development. Vol 22(7): 637-656.

Moleong, Lexy. 1996. Metodologi Penelitian Kualitatif. Remaja Rosda karya . Bandung.

Mondy, R.W., dan R.M. Noe. 2005. Human Resource Management ( $9^{\text {th }}$ ed.). New Jersey, Pearson Prentice Hall.

Morris, J. 2004. The future of work: organizational and international perspectives. International Journal of Human Resource Management. Vol 15 (2): 263-275.

Siauw, Vincent. 2002. Strategic Talent Management. Six Edition. West Publishing Company

Simarmata, DJ, A. 1983. Operation Research: Sebuah Pengantar. PT. Gramedia. Jakarta.

Schuller, RS dan Jackson, SE. 1990. Human Resources Management Positioning For The 21th Century. Six edition. West Publishing Company.

Sofo, Francesco. Terjemahan Jusuf Irianto. 2003. Pengembangan Sumber Daya manusia. Airlangga University Press. Surabaya.

Skinner, J., I. Pownall, \& P. Cross. 2003. Is HRD practised in micro-SMEs?. Journal Human Resource Development International. Vol 6 (4): 475-489.

Strandholm, K., K.Kumar, dan R. Subramaniam. 2004. Examining the interrelationships among perceived environmental change, strategic response, managerial characteristics, and organizational performance. Journal of Business Research. Vol 57(1)58-68.

Supriyono, F.X., dan IGN.R. Setyawan. 2004. Identifying the degree of readiness of SME in Bandung for AFTA. Manajemen Usahawan Indonesia. Vol 64(33): 3-11. 
Tambunan, T.T.H. 2002. Usaha kecil dan menengah di Indonesia: beberapa isu penting. Jakarta, Penerbit Salemba Empat.

Tovstiga, 2004. Preparing Russian small innovative enterprises for international competitiveness: a scoping study. Journal of International Entrepreneurship. Vol 2 (1): 89-108.

Vermeulen, P. 2004. Managing product innovation in financial services firms. European Management Journal. Vol 22 (1): 43-50.

Whitener, E.M. 2001. Do "high commitment" human resource practices affect employee commitment? A cross-level analysis using hierarchical linear modeling. Journal of Management. Vol 27(3): 371-390.

Winardi, J. 2004. Manajemen perilaku organisasi. Bandung, Prenada Media. 